\title{
Risk Management Practices: A Survey of Micro-Insurance Service Providers in Kenya
}

\author{
Amos Gitau Njuguna (Corresponding author) \\ Chandaria School of Business, United States International University, P.O Box 14634-0800, Nairobi, Kenya \\ Tel: 254-72-551-6530Ｅ-mail: amnjuguna@usiu.ac.ke
}

\author{
Abigael Arunga \\ Chartis Insurance Company, Nairobi, Kenya
}

Received: November 2, 2012

Accepted: December 13, 2012

Online Published: December 23, 2012

doi:10.5430/ijfr.v4n1p132

URL: http://dx.doi.org/10.5430/ijfr.v4n1p132

\begin{abstract}
In the recent past, concerted efforts have been made to encourage financial service access to the poor starting with microfinance and subsequently micro-insurance. With complexity of insurance and the vulnerability of the target market, there are inherent risks that insurance companies face in serving the low-end market. This study documents these risks, discusses the strategies that Kenyan insurance companies are using to mitigate the risks and discerns creative strategies to minimize them. Purposive sampling was used to select 8 companies that offer micro-insurance products in Kenya, from which 49 key informants responded to the survey. Visual binning approach was used to describe the data, while statistical tests of correlation and association were carried out by use of Pearson Correlations and Chi-Square tests. The study singled out the most ubiquitous risks facing micro-insurance providers as; diseconomies of scale resulting from low penetration, limited distribution channels, correlation risks and rigid regulatory framework. The strategies being used to counter the risks include; use of technology to lower administration costs, control of moral hazard and adverse selection, thorough scrutiny of claims, development of risk measurement models and continuous monitoring of the clients. Micro-insurance service providers are advised to invest in research and actuarial services to improve pricing of the products, develop innovative distribution channels, adopt technology conscious partnerships and devise flexible premium payment terms to enhance control of micro-insurance risks. The industry regulator (Insurance Regulatory Authority) is further advised to ensure that micro-insurance policies are drafted in simple language understandable by the clients.
\end{abstract}

Keywords: Micro-insurance, Risk management, Micro-insurance risks

\section{Introduction}

Micro-insurance entails delivery of insurance products to participants at base of the pyramid. It is offered to shield clients against specific risks in consideration for premiums matching the possibility of occurrence of the risk (Makove, 2011). Conceptual differences exist between micro-Insurance and other forms of insurance since micro-insurance has lesser assets and lower volatile premiums. Although low-income earners face risks and economic shocks that might be the same as conventional insurance clients, the low-end market is more susceptible due to limitation of resources and knowledge (Churchill, 2006; Maleika \& Kuriakose, 2008), are not able to mitigate risks compared to their higher-income participants; and in case of economic loss from perils, they are less equipped to cope with the aftermaths. Micro-insurance therefore serves as their best bet in building financial confidence and wealth restoration in the event that risks materialize (Butt, 2010).

The poor face two types of risks namely; idiosyncratic (specific to the household) and covariate (common to all). To combat these risks, they have traditionally used risk pooling (for instance funeral and burial societies), income support (for instance credit arrangements and transfers) and informal insurance or risk-sharing schemes such as grain storage, savings, asset accumulation and loans from friends and relatives (Bhattamishra \& Barrett, 2008; Tadesse \& Brans, 2012). However, the prevalent forms of risk management (in kind savings, self-insurance, mutual insurance) which were appropriate earlier are no longer adequate and feasible (Pierro \& Desai, 2007; Giesbert \& Steiner, 2012) 
as they are limited in outreach and the benefits typically cover a small portion of the loss (Churchill, 2006), offer limited protection, low returns for households, and are prone to breakdown during emergencies (Bhattamishra \& Barrett, 2008). Formal insurance instruments can offer superior risk management alternatives, provided poor households can access these services (Maleika \& Kuriakose, 2008).

World bank (2011) estimates that 1.2 billion (20\%) of the world population lives on less that $\$ 1 /$ day (extreme poverty), another 1.8 billion (30\%) lives on less than $\$ 2 /$ day (moderate poverty). Of these poor, only one to three percent has access to any type of insurance products (Tucker, 2007). The lack of formal insurance choices does not stop these poor from attempting to mitigate risk. In fact Tucker (2007) shows that poor urbanites spend about 9.2\% of their income attempting to reduce disaster risk without the advantage of insurance. This suggests that micro-insurance services are in demand and have not been effectively supplied.

Empirical studies show that access to micro-insurance products significantly impacts on how participants deal with unexpected shocks, smooth their income, protect their assets, and avoid falling into debt traps (Micro-Finance Center $[\mathrm{MF}], 2012$ ). Despite the benefits of micro-insurance, the global outreach is still limited (Roth, McCord \& Liber, 2007). Globally, of the 100 poorest countries 77 had some form of micro-insurance products with the micro-insured population being estimated to be 78 million people (Roth et al, 2007) where Asia accounted for $86 \%$ of the global micro-insurance outreach, which accounts to only $2.7 \%$ of the poor population in Asia. Further, the poor micro-insured in Africa and Latin America was $0.3 \%$ and $7.8 \%$ respectively.

Wipf, Kelly and McCord (2011) cites Micro-insurance Centre that analyzed 87 countries in which South Africa (ranked 32) and Namibia (ranked 44) were the only sub-Saharan African countries that rank relatively high in terms of density. Angola (ranked 74), Kenya (ranked 82) and Nigeria (ranked 86) are positioned at the lower end of the ranking. However, ILO figures show that, in Africa alone, the number of micro-insurance policies rose by $80 \%$ between 2005 and 2009. Nevertheless, many low-income people, in Africa, do not understand what insurance is or how it works and penetration still remains low (Morelli, Onnis, Ammann \& Sutter, 2010). An earlier study by Roth et al. (2007) which studied 100 poorest countries found Uganda to have almost half of micro-insurance covers in Africa; excluding South Africa. The low micro-insurance coverage could partly owe to the fact that that insurance markets in most developing countries are still in their infancy (Swiss Re, 2007; Arun \& Steiner, 2008).

In Kenya, low income target market is generally ignored by the mainstream commercial and social insurance schemes and has not, for a long time, had access to appropriate micro-insurance products (Mbogo, 2009). While over $90 \%$ of the population in Kenya is exposed to many risks in life, with the poor being the most exposed, the overall insurance sector serves $8.4 \%$ of the total population (Ogodo, 2010). Key challenges include; low penetration, absence of a savings culture and low incomes.

Although micro-Insurance has made significant difference in developing countries challenges are still prevalent (Patel, 2002; Prud'Homme \& Traoré, 2007). The challenges relate to high administrative costs, irregular income by the clients, poor product design, weak contract enforcement laws, illiteracy and lack of awareness (Preker, Carrin, Dror, Jakab, Hsiao \& Arhin-Tenkorang, 2002; McCord \& Roth, 2006). It is therefore imperative that insurance companies develop micro-insurance risk management models.

Empirical studies (Brown \& Churchill, 2000; Siegel, Alwang \& Canagarajah, 2001; Patel, 2002; Fischer \& Qureshi, 2006; Bhattamishra \& Barrett, 2008; Cummins \& Mahul, 2009a; Arun \& Steiner, 2008; World Bank, 2011) have dwelt on micro-insurance in the context of social protection, other studies (Brown \& MCCord, 2000; Cohen \& Substad, 2005; Garand \& Wipf, 2006; McCord \& Roth, 2006; Churchill, 2007; AKI, 2008; Ngahu, 2009) have investigated the nature of the uninsured markets in various parts of the world, Butt (2010) has conducted case studies of various countries, Skees et al, (1999); Prud'Homme \& Traolle (2007); Chandani (2009), Cummins \& Mahul (2009b); Mbogo (2009); Morelli, et al (2010) studied the various models that are useful in implementing micro-insurance products. Other studies such as McCord (2001); Pierker et al, (2001) and Gitonga, (2009a; 2009b) have been devoted to the provision of micro-health insurance while Weber (2002), Maleika and Kuriakose (2008); Zingales (2009) and Makove (2011) have addressed the need for government support in providing micro-insurance products. Another theme widely addressed by Rodriguez and Miranda (2004); Roth et al (2005); Roth et al (2007) and Tremblay, Quiron, Langlois and Klutze (2006) relate to the good practices in micro-insurance provision. This study focuses on an area that has not been expressly addressed by other studies namely; risk management in the context of micro-insurance provision.

This study seeks to determine the unique risks facing micro-insurance companies, document how Kenyan insurance companies are coping with the risks and provide the policy makers with pragmatic strategies that can be used to mitigate the risks at both the firm and industry levels. 


\section{Literature Review}

\subsection{Risks Faced by Micro-Insurance Service Providers}

Product design risk in the context of micro-insurance results because potential clients are exposed to a myriad of risks, all of which cannot be feasibly insured (Roth et al, 2007; Mbogo, 2010). The products formed fail to meet consumer expectations (Brown \& McCord, 2000). Mbogo (2010) finds micro-insurance products to be general and inadequate in meeting the user needs in Kenya. Additionally, there is inadequate differentiation between products from different insurance companies, making it difficult for consumers to distinguish between competitor offerings in terms of product features (AKI, 2008). Product design further affects the quality of the service. Although micro-insurance clients may not afford high prices, they need high quality products, in fact better-quality micro-insurance product (faster settlement of claims, fewer exclusions and wider coverage) to attract them to insurance. Prahalad (2005) shows that the poor too are brand conscious.

Moral hazard in the context of micro-insurance relates to fraudulent activities where clients overvalue their assets or make false (Churchill, 2007). Moral hazard is prevalent in the micro-insurance business as clients can gain a lot and have little to lose (Weiss, 2006). The physical remoteness of the market served, makes it difficult for the insurer to verify the existence of assets and the diligence that the insured places on insured assets against loss probabilities. Moral hazard endangers customers' protection and distorts the financial viability of the insurer (Dalal \& Morduch, 2010).

Adverse selection occurs because individuals who are predisposed to risks or expectations of risks are more likely to purchase insurance implying that a disproportional part of high risk individuals become members of an insurance scheme (Weiss, 2006) raising the cost of insurance provision. Adverse selection destabilizes the insurance system because the ideology of risk-pooling assumes that a lower proportion of the insured will suffer losses (Brown \& Churchill, 2000)

Micro-insurance pricing presents significant challenges because of the need to balance prices, costs, sustainability and affordability. Price charged should cover all claims and operating expenses and generate a profit. Low-income people buy insurance if the products meet their needs and are fairly priced (Brown and McCord, 2000). As such, micro-insurance policy premium is often lower than the administrative cost incurred, thus unprofitable in the absence of economies of scale. The operating expenses commonly included in the premium are distribution costs, underwriting expenses, claims assessment expenses, transaction cost of collecting premiums and administration costs (Weiss, 2006).

Risk correlation or covariance occurs when a significant cross-section of policyholders suffer economic loss from the same risk (Azam \& Amai, 2012). The capacity of insurers to provide micro-insurance products depends in part on risk source, correlation, frequency and intensity. Such risks can be low frequency but with high economic impact (catastrophic risk), or high frequency with low economic impact (non-catastrophic) (Maleika \& Kuriakose, 2008). Whichever way covariant risk is a major challenge for micro-insurers (Weiss, 2006).

Regulatory risks for micro-insurance depend on the country, institutions and product involved (McCord, 2011). Regulations for micro-insurance typically specify the delivery channels, intermediary market, registration and product approvals (McCord, 2011). Regulation can be beneficial, but enforcing the laws of conventional insurance on micro-insurance hampers the growth of the sector (Churchill, 2007; IAIS, 2008). Makove (2011) documents the inhibiting regulations in Kenya as minimum capital requirement, licensing, distribution channels and investment regulations. While liberal insurance legislation result to expansion of insurance services rigid legislation can hamper growth of micro-insurance business. Appropriate legal infrastructure not only safeguards the interests of policyholders but also minimizes institutional risks (Churchill, 2007).

Income variability is a major challenge in micro-insurance provision since the target market consists of selfemployed people and workers in the informal sector (Churchill, 2007; Dalal and Morduch, 2010) whose incomes are often low and unpredictable. Additionally, most micro-insurance models allow for contribution of small denominated high frequency premiums (Prud'Homme \& Traole, 2007) which have a direct effect on per unit transaction costs.

The inadequacy of distribution channels risk is inherent in all micro-insurance initiatives. Generally micro-insurance products are delivered through Microfinance Institutions (MFIs), post offices, Non-Governmental Organizations (NGOs) or through company employees (Roth et al, 2007). Micro-insurance charges low premiums hence the distribution costs must be minimized (Mahul \& Stutley, 2010). Insurers are often constrained by lack of low cost distribution channels that can reach low-income earners' target market. For most insurers, premium collection and claims settlement occurs through direct contact between the policyholder and the relevant department within the 
insurer; with remoteness, low confidence in insurance products and low awareness amongst clients, this method of distribution of the products pose significant risk (Fischer \& Qureshi, 2006).

Micro-Insurance is expensive to implement at the start-up phase since big expertise is needed to price and market the product and establish triggers; and, needs sufficient historical data and precise measurements to develop the index (Skees et al, 1999).

\subsection{Micro-Insurance Risk Management Strategies}

\subsubsection{Efficient Distribution Channels}

The models used in distributing micro-insurance products must be pragmatic, cost effective and transparent. The main distribution model involves use of Community-Based Organizations (CBO), local community organizations, MFIs, NGOs and or cooperative societies (Garand \& Wipf, 2006). Despite using partners, the insurer pools, manages and absorbs the risk. Microfinance institutions and commercial banks also directly market micro-insurance products to potential clients in the provider model (Maleika \& Kuriakose, 2008). This model has a wide reach in the general insurance market but suffers from high transaction costs, when applied in low-income, low-margin markets such as rural areas with dispersed populations (Maleika \& Kuriakose, 2008). Osero (2009) suggests funeral parlours, direct selling, mobile services, shops, supermarkets, petrol stations and public utility companies as distribution channels that can be explored for micro-insurance delivery.

\subsubsection{Price Reviews}

Generally insurers lack accurate data to enhance accurate pricing hence the prices charged may be less or far much more than the costs. To address this problem insurer can allow an error margin and then make adjustments once the claims are lodged (Patel, 2002). Churchill (2007) advises micro-insurers, to constantly make price adjustments by using actuarial services.

\subsubsection{Thorough Scrutiny of Micro-Insurance Claims and Applicants}

Scrutiny of claims minimizes moral hazard (Dalal \& Morduch, 2010). The scrutiny criteria for claims must be embedded at the product design stage. One of the strategies is to use relationship community structures (Dalal and Morduch, 2010) where the clients are sensitized on the need to make genuine claims. Screening applicants helps to minimize adverse selection (Siegel et al, 2001). Risky clients are detected and excluded from coverage.

\subsubsection{Flexible Payment of Premiums}

To overcome income variability, micro-insurance providers need to design premium payment methods that ensure maximum collection. Policyholders should be asked to pay when they have the money for example at harvest time, or when they receive a loan or a government cash transfer (Siegel et al, 2001; Gitonga, 2009a) in addition to bancassurance and mobile money transfers (Mbogo, 2009).

Four models of premium collection according to Maleika and Kuriakose (2008) include the premium linked model where micro-insurance products are linked to other final products especially loans. Automatic premium deduction from savings account model involves a direct deduction from the policyholder's bank account. An alternate option is the interest-premium model, where premiums are paid from savings account interest. Lastly, the door-to-door premium collection model ensures physical collection of premiums either by going door to door to collect individual payments or through group mechanism where many payments can be collected at once. For micro insurance to succeed, the premium payment mechanism must balance between efficiency, sustainability and client capacities.

\subsubsection{Niche Marketing}

In assessing the market for micro-insurance, emphasis should be placed on size of the geographical region, number of potential clients, culture and capacity to pay (Churchill, 2007). Adequate market research on helps to determine the potential market and identifies those segments of the market that have specific usage and attitude problems with respect to micro-insurance. The findings should be used to devise plans to recruit clients (Prahalad, 2005). Insurance company should anticipate and satisfy the need of its varying clients and thus gain deep penetration in the different regions. As such, insurance companies should come up with insurance products targeting specific markets.

\subsubsection{Partnering with Other Intermediaries in the Value Chain}

Linking micro-insurance programs to other intermediaries is a helpful strategy to compensate for some risks by minimizing distribution costs, while increasing outreach, affordability and economies of scale (Churchill, 2006). The insurer may use NGOs, MFIs, agribusiness firms or local banks to liaise between the customer and insurance company, and manage marketing and administration functions. 


\subsubsection{Public Awareness}

Many clients are sceptical about paying premiums for an intangible product with future benefits that may never be claimed and they are often do not trust insurance companies. Some insurance firms provide information and education campaign among low-income households on the need for risk protection through such schemes as micro-insurance and to differentiate micro-insurance from the conventional insurance products (Siegel et al. 2001). For example, VimoSEWA (India) realized that its claims rates were much lower than they should have been, so it increased efforts to educate policyholders about the claims process. The micro-insurer also gave its members stamped postcards to make it easier for policyholders to contact their agents if they needed assistance.

Insurance policies must be easy to understand, particularly in places where levels of insurance illiteracy, or indeed illiteracy in general, are high. Unless micro-insurance is seen to settle losses (the basic minimum requirement), customers lose interest in the same. For a micro-insurance scheme is to succeed, it needs to satisfy, among other conditions; comprehensibility and understandibility by the clients (Morelli et al. 2010).

\subsubsection{Re-Insurance}

Reinsurance or risk transfer is vital to the short and long-term viability of micro-insurance. Lack of reinsurance of underwritten policies or access there to hampers the mass market principle and threatens the financial solvency of existing and potential insurance firms into micro-insurance owing to potential losses, as well as their millions of existing and potential low-income clients (Tremblay et al. 2006). Some micro-insurers strengthen the viability and the financial capacity of the schemes through reinsurance or guarantee funds. Prahalad (2005) echoed this point by stating that well-managed insurance companies use reinsurance to manage risk, although reinsurance is not necessary in all situations. Larger insurance companies that are involved in micro-insurance, do not purchase reinsurance for their smallest polices because they cover many people for small sums over a large geographical area (Siegel et al. 2001). However, micro-insurers without significant reserves and without portfolios diversified between traditional and micro-insurance explore reinsurance arrangements (or at least insurance for catastrophic losses) (Prahalad, 2005).

\subsubsection{Responsive Regulation}

Regulation plays a key role in bolstering trust in insurance and is an important factor in the reducing the micro-insurance risks (Zingales, 2009). The regulatory environment should encourage tapping of a wide range of distribution channels for micro-insurance (Makove, 2011). Insurance laws, regulations and rules have developed over time with traditional insurance in mind. These traditional products continue to be inaccessible to the poor. To enhance micro-insurance, legal action should be taken on the errant insurance firms, fraudulent agents and deceptive clients (Morelli, et al, 2010).

\subsubsection{Development of Risk Measurement Models}

Micro-insurance service providers should develop a simple and sound micro-insurance policy framework to grow and develop the business. The firms should carry documentation of existing risk management schemes and micro-insurance practices adopted by insurers including collection of adequate data on risk prevalence of areas/clientele demographics (Makove, 2011). Insurance firms can also develop risk measurement models for micro-insurance products and during underwriting, considering the unique needs of the low-income market, namely; customer needs, product design, delivery systems and even business models.

\subsubsection{Social Welfare (Sponsorship)}

Insurance firms can mitigate risks by using sponsors in the micro-insurance schemes which also enable them offer their services at subsidized rates (Maleika and Kuriakose, 2008). For example, ServiPerú's cover includes a funeral benefit (Rodríguez and Miranda, 2004). The organization has negotiated a discount from associated funeral service providers in exchange for bringing in large volumes of business. Consequently, low-income households have access to a funeral of the same quality for less money by going through the insurer. Micro-insurance schemes that emerge from the social protection perspective are either financed in whole or in part by government funds or a strategy for sustainability is to gain access to these subsidies eventually (Roth et al., 2005).

\section{Research Methodology}

\subsection{Research Design}

The study used a descriptive research design as it sought to determine the micro-insurance risk management practices of insurance companies in Kenya. Descriptive research design utilizes elements of both quantitative and qualitative research methodologies to offer description of the state of affairs as it exists at present (Burns, 2000) and 
can involve collections of quantitative information that can be tabulated along a continuum in numerical form and is important in reducing the data to manageable form. The researchers also reviewed documents that were obtained from the Insurance Regulatory Authority (IRA) and Association of Kenya Insurers (AKI) on micro-Insurance. This data was used to strengthen the arguments that were drawn from the primary data which at times is subjective based on the respondents' predisposition at the time of data collection.

\subsection{Population and Sampling Design}

The population of the study consisted of the 45 insurance companies registered in Kenya by 30 June 2012. Purposive sampling was used to pick 8 companies that offer micro-insurance products. The respondents were managers who deal with micro-insurance products. The study targeted 7 respondents from each company (total 56) out of which 49 usable responses were returned (response rate $=87.5 \%$ ).

\subsection{Measuring Instruments}

Primary data was collected by use of questionnaires that had four main sections. The first section sought to collect data on the line of business of the insurance company, experience of the respondent, department in which they work, position in management, number of years the company has offered micro-insurance and the micro-insurance product offered. The second section anchored the risks highlighted in the literature review on a 5 point scale. The risks were; product design, adverse selection, moral hazard, pricing, correlation of risks, regulatory, fraud, premium default, inadequate distribution channels and low penetration. The respondents were asked to rate the extent to which they experienced the risks ( $1=$ not at all, $2=$ little extent, $3=$ moderate extent, $4=$ great extent and $5=$ very great extent). The third section postulated risk management measures currently applied by the companies and put them on a 5 point likert scale asking the respondents to state the extent to which they used the approaches to manage risks inherent in micro-insurance. The measures were; constant monitoring of clients, control of moral hazards by denying claims to self afflicted losses, price revisions, use of technology, excluding highly risky clients, careful scrutiny of claims, development of risk measurement models, use of actuaries in pricing, flexible premium payments, partnering with other firms, public awareness and re-insurance. The fourth section asked respondents to rate the strategies that can be applied (as good practice) to manage risks that micro-insurance service providers are prone to on a 5 point likert scale. The strategies were; use of technology to reduce administration and transaction costs, innovative distribution channels, public awareness campaigns, niche marketing, use of sponsors to subsidize costs, flexibility in premium payments, price adjustments, forming risk reference bureaus and writing policies in languages understandable in the target market. After each section, an open ended question was included asking respondents to state any other factors that they considered important and was not included in the closed ended questions.

\subsection{Reliability and Validity of the Measuring Instruments}

The Cronbach alpha coefficient was used to calculate the internal consistency of the measuring scales. All the scales gave Cronbach alpha values in excess of 0.7. Sufficient proof of content and criterion-related validity was established on the basis of the literature review and discussion with key informants in the micro-insurance industry in Kenya.

\subsection{Research Procedures}

Before actual data collection, a pilot study was done on 9 respondents. The results of the pilot study were used to refine the measuring instruments by removing redundancies and inconsistencies in the instruments after testing its validity and reliability. All the applicable research ethics were adhered to specifically; the respondents' right to privacy, consent, voluntary participation and right to withdraw while in process and avoiding embarrassment, stress and discomfort to the respondents.

\subsection{Data Analysis}

Percentages, means and standard deviations were calculated to help in describing the data. Additionally, Pearson Correlations and Chi-Tests were calculated to determine the level of association between the variables of interest. Visual binning was eventually applied to determine the most severe risks facing micro-insurance providers and the effectiveness of the risk management strategies postulated in the study.

\section{Results}

\subsection{General Information}

The micro-insurance products available in Kenya include agriculture (crop and livestock), funeral expenses, medical covers, micro business losses, life, car insurance; education and domestic assets (table 1). Table 1 further shows that $88 \%$ of the companies offer medical covers. These companies are predominantly composite (offer both life and 
general insurance) and exclusively serve the Kenyan market. The companies have offered micro-insurance services for less than 3 years $(12.5 \%), 4$ to 5 years $(37.5 \%)$ and more than 6 years $(50 \%)$. Table 2 shows that $59.2 \%$ of the respondents had worked for 2 years or less; $20.4 \%$ had worked for over 6 years; $18.4 \%$ had worked for 5 - 6 years; and $2.0 \%$ had worked for $3-4$ years. Further $45 \%$ of the respondents were at the operations level; $35 \%$ in the middle management; $16 \%$ in lower level management and $4 \%$ were in top-level management. Additionally, $63.3 \%$ of the respondents work in the underwriting departments; $26.5 \%$ work in other departments such as finance, marketing and product development departments; $8.2 \%$ worked in risk department; while, $2 \%$ worked in the claims department. The study sought to establish the chances of renewal of the micro-insurance policies underwritten. Table 2 also shows that $30.6 \%$ of the respondents felt that the policies had $61-80 \%$ chance of renewal, $28.6 \%$ alluded to a $41-60 \%$ chance, $26.5 \%$ estimated a $21-40 \%$ chance and $12.2 \%$ expected a $20 \%$ or less chance.

\subsection{Micro-Insurance Risks Faced by Insurance Companies in Kenya}

Table 3 shows the perceptions of the respondents with regard to risks faced by micro-insurance providers. It discloses most severe risks experienced by micro-insurance service providers as low penetration (mean 4.06), constrained distribution channels $($ mean $=3.69)$, rigid regulatory framework (mean $=3.41$ ) and correlation of risks $($ mean $=3.20)$. Although pricing is also considered a severe risk, the respondents did not perceive product design, adverse selection, moral hazard, fraud and premium default as serious risks in offering micro-insurance products.

The respondents mentioned other micro-insurance risks (open ended questions) as mismatch between affordability and sustainability; lack of technical expertise on micro-insurance; inaccessibility to remote areas; inappropriate tools for data collection especially in weather forecasting for index-based weather insurance; lack of capacity for early prediction of climate hazards, culture of mistrusting insurance companies, high administration and transaction costs, high lapse rates especially where claims have not occurred; mis-selling by the agents and high exposure to catastrophic losses.

Table 4 shows a significantly positive correlation between product design challenges and correlation risks inherent in the micro-insurance products $(\mathrm{p}<0.01)$. It also shows a significant positive correlation between experience in micro-insurance business and adverse selection risk faced by the insurance company $(p<0.05)$ and moral hazard risks $(\mathrm{p}<0.01)$. This could be explained by the insurance company's endeavour to increase micro-insurance coverage or penetration with time leading to adverse selection and moral hazard. Table 4 further discloses a significant negative relationship between correlation of risks and the duration that the insurance companies had taken in micro-insurance business $(p<0.05)$. Correlation of risks thus reduces as the company gains more experience in the micro-insurance business. Additionally, a significantly negative correlation was observed between micro-insurance penetration risks and the experience in the micro-insurance business $(\mathrm{p}<0.01)$ implying that penetration risks reduce as the insurance company gains experience in the micro-insurance business. Lastly, table 4 shows a significantly negative correlation between micro-insurance penetration risks and adverse selection risks.

\subsection{Risk Management Practices of Micro-Insurance Service Providers}

All respondents confirmed that insurance companies had risk management policies in place. The risk management practises frequently used by micro-service providers in Kenya (table 5) include using mobile money transfer (3.92), denying claims in case of fraud (mean=3.76), excluding high risk clients (mean=3.57), thorough scrutiny of claims (mean=3.47) constant price reviews (mean=3.39) and development of risk measurement mechanisms (mean=3.35). Other strategies that are rarely used are; constant monitoring of the client's risk profiles (mean=3.29), using actuarial services in risk analysis (mean=3.27), flexing the premium payment (mean=3.24), partnering with other intermediaries in the value chain (mean=3.31), public awareness campaigns (mean=3.3) and re-insurance (mean=3.04).

The respondents mentioned other ways that they deal with risks exposed to them (open ended questions) as automation of processes, bulk processing to reduce administration costs; use of alternative channels such as banc-assurance and affinity groups; undertaking research on climate risk and micro-insurance; requesting government and donors for subsidy; conducting public awareness workshops; allowing discounts in return for no claims; giving education to the insured to assist in risk management; reviewing the technical capability and capacity of the staff to effectively supervise and monitor the operation of micro-insurance and finding out from the other insurance companies the loss experience of a particular insured where the information is available.

Table 6 discloses the Chi-test results for the association between line of business and monitoring of clients risk profile. It discloses a significant relationship between the line of business served by the insurance company and the extent that the companies monitored clients risk profile $(\mathrm{p}<0.05)$. Table 7 discloses a relationship between the 
company's line of business and how they deal with adverse selection risks $(\mathrm{p}<0.05)$ implying that composite companies manage their risks better than exclusively life or general insurance. Table 8 portrays a relationship between the line of business served (whether life, general or composite) with the monitoring of claims to prevent fraud on the same $(p<0.05)$ implying that composite companies manage risks differently from the life and general companies. Table 9 depicts a significant relationship between the market served and the use of mobile money transfers to pay for the premiums $(\mathrm{p}<0.05)$ implying that risk management practices are related to the market served (global, regional or local). Table 10 shows that market served by the insurance company (local, regional or global) would influence the development of risk measurement models $(\mathrm{p}<0.05)$. Table 11 shows that the market served by the insurance company would influence the reinsurance of micro-insurance product practiced by the same as a micro-insurance risk mitigating practice $(\mathrm{p}<0.05)$.

\subsection{Strategies to Deal with Micro-Insurance Risks}

Table 12 discloses the most effective strategies in micro-insurance risk management as; use of actuaries principles in product pricing (mean $=4.53$ ), public awareness $($ mean $=4.45)$, flexing the payment mode for premiums (mean $=4.37$ ), embracing technology to reduce costs $(m e a n=4.31)$, writing micro-insurance policies in simpler terms (mean $=4.33$ ) and developing innovative distribution channels $(\operatorname{mean}=4.24)$. The strategies that are less effective are; target or niche marketing (mean=3.94), subsidies by sponsors $(m e a n=3.90)$ and establishment of risk reference bureaus (mean=3.98).

Table 13 depicts a significant association between line of insurance business and the needs to reduce administration cost through technology and partnerships; that is, products offered in the market (whether life, general or composite) would influence the need for partnership with other entities and use technology $(p<0.05)$. For instance, crop insurance would influence partnership with organizations such as weather stations (Metrological Department) for Index Insurance. Table 14 depicts that line of business served by the insurance companies would influence the need for adopting flexible premium payment terms. For instance, premium payment for life insurance can be staggered throughout the year and paid using mobile money transfer. Table 15 on the other hand shows that market served by the insurance companies would not influence the need for conducting public awareness campaigns and education on micro-insurance benefits.

Lastly, Table 16 illustrates that market served by the insurance companies would influence the need for the companies to develop selective targeting of geographical areas and clientele demographic to reduce adverse selection. $(\mathrm{p}<0.05)$ owing to the fact that geographical areas experiences different risks predisposition.

\section{Discussion of Results}

\subsection{Risks Faced by Micro-Insurance Service Providers in Kenya}

The study identifies the major risks facing micro-insurance companies as low penetration of insurance services, constrained distribution channels, regulatory risks and correlation risks. These findings concur with Weiss (2006); Churchill (2007) and Makove (2011). Low penetration arises due to lack of public confidence in insurance services in Kenya. Churchill (2007) attributes the problems with distribution channels to the use of traditional channels that serve the high-end market. On the other hand Maleika and Kuriakose (2008) link the constrained channels to regulations regarding capitalization and distribution channels used. Maleika and Kuriakose further established that low pricing of micro-insurance products makes it unattractive to brokerage firms or agents as they get low commission hence constraining the distribution channels further. Key regulatory risks that micro-insurance service providers face include minimum capital requirements, licensing, distribution channels and investment regulations (Makove, 2011). Correlation of risks has also been found to be a major problem in micro-insurance service provision primarily because the clients who purchase the insurance are those who have higher chances of loss (Maleika and Kuriakose, 2008). Correlation risks are however addressed as the micro-insurance provider gets more experience in offering the services. Experienced micro-insurance providers must however check on the adverse selection risk because they tend to attract more clients thus increasing the selection risk.

\subsection{Micro-insurance Risk Management Practices of Insurance Firms}

To mitigate risks the study found that insurance firms control moral hazard risks by denying claims to self-inflicted or aggravated losses. Weiss (2006) however cautioned firms using this strategy since insurance firms find it hard to authenticate the care that micro-insurance clients give to their assets. Additionally, Brown and McCord (2000) cautions that many claims in the micro-insurance context are paid without verification due to the high costs of performing inspections partly attributed to owing to low premium charged and geographical locations. The study findings concur with Mbogo (2009) who show that the micro-insurance service providers in Kenya collect premiums 
by use of mobile money transfer to lower administration and transaction costs. The study established that insurance firms in Kenya mitigate against adverse selection by excluding areas or clients of high risks probability, reduce adverse selection by screening applicants, and exclude fraudulent clients. These methods have been found to be useful in risk management in the context of micro-insurance service providers (Patel, 2002).

The study found that insurance companies conduct constant micro-insurance price reviews/revisions so as to reduce the risk of cost incurred being higher than the price charged or the policy being too expensive to be afforded by the low-end market. In tandem, Patel (2002) also established that to minimize the risk of premium got being lower than claims paid, the insurance companies constantly reviews policy prices and establish a big margin for error and then make adjustments, upwards or downwards once the claims experience starts rolling in. Likewise, Brown and McCord (2000) found that management information systems are vital to track the performance of policy premium with regards to claim payment.

The study finds that insurance companies in Kenya partner with other companies to minimize risks so as to benefit from each others' competitive strengths. Churchill (2006), for instance, advocated for linking micro-insurance programs to other intermediaries and establishing partnerships to minimize distribution costs. The study further established that insurance companies conduct public campaigns on insurance to boost public awareness in insurance, thus, raise penetration. In concurrence Siegel et al (2001), documents that this practice boosts uptake of micro-insurance products. The study also found that insurance firms give clients a flexible premium payment terms to avoid non-payment. Mbogo (2009) concurs with this and attributes it to lack of a stable income flow amongst the low income earners and advises that premium payments procedures be flexible to allow participation.

The study shows that Kenyan companies rarely reinsure micro-insurance products underwritten, a fact that Siegel et al. (2001) attributes to the cost inefficiency associated with micro-insurance policies due to the low premiums. Contrary to these findings, Prehalad (2006) argues that all risks should be reinsured.

\subsection{Micro-Insurance Risk Management Strategies}

Insurance companies should invest in research and development and actuarial services to help in pricing of products and risk mitigation. These findings concur with Churchill (2007) who advise insurance firms to invest in research and development to enhance determination of financial feasibility of insurance products, the number of subscribers required for the product to be profitable and pricing of the products. We advise that insurance firms conduct public awareness campaigns and education on Micro-Insurance benefits. Prahalad (2005) and Morelli, et al (2010) agrees citing the low knowledge on financial services amongst participants in the bottom of the pyramid. The study further advises insurance companies to make use of flexible premium payments underscoring Ogodo (2010) assertions. This can be achieved by investing in better technology innovative distribution channels and allowing more frequent payments of premiums. The study, further, established that legislation should allow micro-insurance policies to be written in languages comprehensible to the locals as earlier suggested by Makove (2011).

To keep claims costs down, insurers should adopt partnerships or seek sponsorships in the policies from firms up or downstream of the policy insured concurring fully with Rodríguez and Miranda (2004); Roth et al, (2005); Gitonga (2009). Partial sponsorship enables micro-insurance service providers to subsidize the premiums. Further, the findings indicated that insurance firms need to formulate innovative distribution channel such as using agents. Maleika and Kuriakose (2008) underscore this point by recommending insurers to use existing distribution channels such as banks (bancassurance), retailers or micro-finance institutions (MFIs).

Micro-insurers need to adjust their prices to reflect loss or offer discount especially where perceived high risk areas turn-out not to be. This concurs with Churchill (2007) who recommend that micro-insurance providers make adjustments once they start getting the claims. The study recommends that insurance firms develop selective targeting of geographical areas and clientele demographic to reduce adverse selection. Segmenting the market by particular types of insurance and estimating the incidence of the risk event for a particular population in a defined geographic location and within a specified time period helps in risk diversification (Prahad, 2005). Establishing 'risk reference bureaus' where clients' risk profile can be shared was found to be an effective way to manage adverse selection risks. This according to Prahalad (2005) would be an informative documentation to the insurers on the high risk individuals or geographical areas. Hence, the insurance companies providing micro-insurance products to such markets would charge differentiated pricing.

\section{Recommendations}

Micro-insurance business faces many risks which include moral hazards, adverse selection, rigid regulatory framework among others. We recommend that insurance firms institute risk management department that identifies 
and continuously monitors the risks inherent in micro-insurance service provision. The insurance company should evaluate its capacity to deal with such risks, implications to the business and use the intelligence gathered or risk assessed to take appropriate actions suggested by the study. Although insurance companies are using actuarial services in pricing new products, there was no evidence that the same services are used in continuous risk management. We therefore recommend regular use of actuarial services in risk management. This will enable monitoring of the clients' risk profile. Besides, the companies should extensively partner with other companies and reinsure micro-insurance products to minimize cost in underwriting the policies. Creative measures such as establishment of risk reference bureaus and risk based pricing can lead to better risk management.

The study, suggest for regulatory authorities to come up with regulations that foster and not stifle micro-insurance business. These regulations should, thus, lax rules on capitalization and distribution channels for micro-insurance business. Legislation should be allowed to allow co-insurance of micro-insurance risks where different companies conglomerate to cover certain aspect of risks and allow for the policies to be written in a language understandable to the consumers.

\section{Limitations of the Study and Suggestions for Further Research}

The key limitations of these study stem from the fact that the study relied on respondent's opinions to draw its inferences. Although the major findings seem to concur with prior studies, $59.2 \%$ of the respondents had been in the micro-insurance services sector for less than 2 years. Additionally, the study used self constructed instruments to draw the inferences. It means that these instruments had not been tested elsewhere hence the diversity in the answers to the open ended questions.

We suggest four areas for further research. First we suggest that study be undertaken on the ideal regulatory structure for micro-insurance service providers in Kenya. Second, we suggest that research be undertaken to discern the factors that affect risk management policies adopted by micro-insurance service providers. Thirdly, we suggest that research be undertaken to discern the effect that factors such as religion and culture have on uptake of micro-insurance services in Kenya. Lastly, we suggest that study be undertaken from the demand side aspect of micro-insurance since this study addressed the supply side.

\section{Conclusions}

This study makes important discoveries. To succeed, regulators need to keenly address a myriad of risks which discourage micro-insurance firms from serving the low-end consumer market segment. These risks include lack of demand for the insurance products (low penetration), limited distribution channels and regulations that limit distribution channels and capitalization. Additionally, the micro-insurance service providers need to enhance the use of technology to lower their costs, partner with others in the value chain, constant review their prices (up or down) depending on the circumstances and use actuarial services to perform risk analysis not only for their new products but also on existing products. Insurance companies can further seek subsidies from donors and government to be able to offer affordable micro-insurance products.

Lastly, the study appeals to the regulators to reconsider the laws that guide operations of the micro-insurance service providers to better address capital requirements and distribution channels.

\section{References}

Arun, T., \& Steiner, S. (2008). Micro-Insurance in the Context of Social Protection. BWPI Working Paper 55 (October), pp 2-6.

Association of Kenya Insurers (AKI). (2008). Understanding the Uninsured Market. Final Report by SBO Research, February, 3-9.

Bhattamishra, R., \& Barrett, C.B. (2008). Community-based Management Arrangements: An Overview and Implications for Social Fund Program Design. Social Protection Discussion Paper No 0830, Washington DC: World Bank.

Brown, W., \& Churchill, C. (2000). Insurance to Low-Income Households Part I: Primer on Insurance Principles and Products. USAID -Microenterprise Best Practice (MBP) Project, October 2000.

Brown, W., \& McCord, M.J. (2000). Microenterprise Best Practices (MBP) Project. Virtual Conference on Microinsurance, Oct $9^{\text {th }}-$ Oct $27^{\text {th }}$, 2000. USAID, Development Alternatives / USAID 2000. 
Butt, B. (2010). Experiences in Micro-Insurance. CARE International. [Online] Available: http://edu.care.org/Documents/Experiences\%20in\%20Micro-Insurance_CARE\%20and\%20Global.pdf (20 October 2012)

Chandani, T. (2009). Microinsurance Business Models. [Online] Available: http://siteresources.worldbank.org/EXTFINANCIALSECTOR/Resources/282884-1242281415644/Microinsruance_ Business_Models.pdf (20 October 2012)

Churchill, C. (2006). Protecting the poor: A micro-insurance compendium. Geneva: International Labour Office.

Churchill, C. (2007). Insuring the low-income market: Challenges and solutions for commercial insurers. Geneva Papers on Risk and Insurance, 32, 401-412. http://dx.doi.org/10.1057/palgrave.gpp.2510132

Cohen, M., \& Sebstad, J. (2005). Reducing Vulnerability: The Demand for Micro-Insurance. Journal of International Development, 17, 397-474. http://dx.doi.org/10.1002/jid.1193

Cummins, J.D., \& Mahul, O. (2009a). Catastrophe Risk Financing in Developing Countries: Principles for Public Intervention. Washington, DC: The International Bank for Reconstruction and Development / The World Bank.

Cummins, J.D., \& Mahul, O. (2009b). Microinsurance Product Development for Microfinance Providers. Manual Developed As Part of the IFAD Project "Facilitating Widespread Access to Microinsurance Services". Micro-Insurance Centre.

Dalal, A., \& Morduch, J. (2010). The Psychology of Microinsurance: Small Changes Can Make a Surprising Difference. Micro-insurance Paper No. 5. Geneva: ILO.

Fischer, K., \& Qureshi, Z. (2006). Cooperatives and Insurance: The Mutual Advantage in Protecting the Poor: A Micro-insurance Compendium. Geneva: International Labour Organization and Munich Re-Foundation Publication.

Garand, D., \& Wipf, J. (2006). The Role of Reinsurance. Microinsurance Newsletter, 3(1), 4-11.

Giesbert, L., \& Steiner, S. (2012). Perceptions of Micro-insurance in southern Ghana: The role of information and peer effects. Deutsches Institut fur wirtschaftsfurschung. Discussion Paper No. 1194.

Gitonga, N. (2009). Health Microinsurance: East African Experience. Insight Health Advisors' Journal, 8(May), 4-5.

Gitonga, N.R. (2009). The long and short of Private Health Insurance (PHI) in Kenya. The Kenya Insurer, July.

International Association of Insurance Supervisors (IAIS). (2007). Issues in regulation and supervision of microinsurance. Issues paper prepared by the IAIS- Consultative Group to Assist the Poor (CGAP) Joint Working Group on Micro-insurance (June).

Mahul, O., \& Stutley, C.J. (2010). Government Support to Agricultural Insurance. Washington, DC: The World Bank. http://dx.doi.org/10.1596/978-0-8213-8217-2

Makove, S. M. (2011). African Policy Approaches: Microinsurance in Kenya. AIO - A2ii Regulators' Workshop, Victoria Falls, Zimbabwe May 26, 2011.

Maleika, M., \&. Kuriakose, A.T. (2008). Microinsurance: Extending Pro-Poor Risk Management through the Social Fund Platform. The World Bank, 5(2), 45-54,

Mbogo, S. (2009). A Look at Samples of Micro-Insurance Products in Kenya. The Kenya Insurer, July.

Mbogo, S. (2010). Insurance Companies Seek New Strategies to Attract Customers. Business Daily, March 10, 2010.

McCord, M. J. (2001). Health care microinsurance - case studies from Uganda, Tanzania, India and Cambodia. Small Enterprise Development, 12(1), 25-39. http://dx.doi.org/10.3362/0957-1329.2001.006

McCord, M. J. (2011). Micro-insurance product development for micro-finance providers. [Online] Available: http://www.microinsurancecentre.org/resources/documents/doc_details/834-microinsurance-product-development-fo r-microfinance-providers.html (20 October 2012)

McCord, M.J., \& Roth, J. (2006). Microinsurance Note 1: What is Microinsurance? Publication Produced for U.S. Agency for International Development, Washington, DC, pp 2-3.

Morelli, E., Onnis, G.A., Ammann, W.J., \& Sutter, C. (2010). Microinsurance: An Innovative Tool for Risk and Disaster Management. Switzerland: Buchdruckerei Davos AG.

Ngahu, B. (2009). Targeting Low-End Market To Increase Insurance Penetration. The Kenya Insurer, July, 13-15.

Ogodo, O. (2010). Kenyan Farmers Get Micro-insurance. Science and Development Network News, March 22, 2010. 
Osero, T. (2009). Micro Insurance: Promoting Access to insurance services by the low income population. The Kenya Insurer, July, 4-6.

Patel, S. (2002). Insurance and Poverty Alleviation: The Cooperative Advantage. The International Cooperative and Mutual Insurance Federation (ICMIF). Available: http://www.ocdc.coop/Sector/Insurance/InsuranceAndPoverty.pdf (May 25, 2012)

Pierro, R., \& Desai, B. (2007). Micro-insurance and DRR: Challenges and Opportunities in the Context of Climate Change. London: Christian Aid Publication.

Prahalad, C. K. (2005). The fortune at the bottom of the pyramid: Eradicating poverty through profits. Upper Saddle River, NJ: Wharton School Publishing

Preker, A.S., Carrin, G., Dror, D., Jakab, M., Hsiao, W., \& Arhin-Tenkorang, D. (2002). Effectiveness of community health financing in meeting the cost of illness. Bulletin of the World Health Organisation (WHO), 80(2), 143-150.

Prud'Homme, M., \& Traoré, B. (2007). Innovations in Sikasso. Microfinance Journal, 3(4), 102-13.

Rodríguez, M., \& Miranda, B. (2004). ServiPerú, Peru; Good and Bad Practices in. Microinsurance. Case Study No. 1. Geneva: CGAP Working Group Publication.

Roth, J., Churchill, C., Ramm, G., \& Namerta, G. (2005). Microinsurance and microfinance institutions: Evidence from India. CGAP Working Group on Microinsurance, Good and Bad Practices, Case Study No. 15, Geneva, ILO Social Finance Programme.

Roth, J., McCord, M.J., \& Liber, D. (2007). The Landscape of Microinsurance in the World's 100 Poorest Countries. Appleton, WI: The MicroInsurance Centre, LLC.

Siegel, P., Alwang, B. J., \& Canagarajah, S. (2001). Viewing microinsurance as a social risk management instrument. Social Protection Discussion Paper Series, 116, Washington, DC, World Bank, Social Protection Unit, Human Development Network: 17-25.

Skees, J., Hazell, P., \& Miranda, M. (1999). New Approaches to Crop Yield Insurance in Developing Countries. EPTD Discussion Paper 55, International Food Policy Research Institute.

Swiss Re. (2007). World insurance in 2006. Premiums came back to "life". Sigma, April, 23-45.

Tadesse, M., \& Brans, M. (2012). Risk Coping Mechanisms and Factors Affecting demand for Micro-insurance in Ethiopia. Journal of Economics \& International Finance, 4(4), 79-91. http://dx.doi.org/10.5897/JEIF11143

Tremblay, C., Quirion, M., Langlois, S., \& Klutzé, F. (2006). MAFUCECTO, Togo: Microinsurance, Good and Bad Practices, Case Study No. 25. Geneva: CGAP Working Group Publication.

Tucker, P. (2007). Microinsurance for megadisasters. The Futurist, 41(3), 16-17.

Weber, A. (2002). Insurance and market failure at the micro-insurance level. In Dror D., \& Preker A.S. (Eds.), Social reinsurance: A new approach to sustainable community health financing (pp. 203-222). Washington, DC, World Bank; Geneva, ILO.

Weiss, D. (2006). Formal Microinsurance in Indonesia: An advantage over informal risk mitigation strategies for low-income people? Diploma Thesis, University of California-San Francisco.

Wipf, J., Kelly, E., \& McCord, M.J. (2011). Improving Credit Life Microinsurance. Microinsurance Paper no9, ILO: 23-35.

World Bank (2011). Poverty and Inequality Analysis. [Online] Available: http://web.worldbank.org/ (March 15, 2012)

Zingales, L. (2009). The future of securities regulation. Journal of Accounting Research, 47(2), 391-425. http://dx.doi.org/10.1111/j.1475-679X.2009.00331.x 
Table 1. Micro-insurance products offered by the responding companies

\begin{tabular}{|c|c|c|}
\hline Insurance Company & Product & Purpose \\
\hline \multirow{3}{*}{$\begin{array}{l}\text { APA } \quad \text { Insurance } \\
\text { Company }\end{array}$} & Crop insurance & Agriculture for crops \\
\hline & Funeral Insurance & Funeral Expense Compensation \\
\hline & $\begin{array}{l}\text { Travel Insurance (Personal Accident } \\
\text { Hospital Cash Insurance) }\end{array}$ & Cover medical bills in case of accidents \\
\hline \multirow{2}{*}{$\begin{array}{l}\text { Chartis Insurance } \\
\text { Kenya }\end{array}$} & Chartis Combined & SMEs cover against business loss \\
\hline & $\begin{array}{l}\text { Flexipack Personal Accident; Student } \\
\text { Personal Accident Cover }\end{array}$ & Cover medical bills in case of accidents \\
\hline \multirow[t]{3}{*}{ CIC Life Assurance } & Microcredit Life; M-Bima & $\begin{array}{l}\text { Compensation for dependants in case of } \\
\text { policyholders death }\end{array}$ \\
\hline & Jijenge Savings & Form of personal long time saving \\
\hline & Jilinde Personal Accident Cover & Cover medical bills in case of accidents \\
\hline \multirow{3}{*}{$\begin{array}{l}\text { Heritage } \\
\text { Company }\end{array}$} & Ngao Motokaa & Micro-insurance for car insurance \\
\hline & Domestic Insurance Packaged & SMEs' cover against business loss \\
\hline & Education Policy & Education policy \\
\hline \multirow[t]{6}{*}{$\begin{array}{l}\text { Jubilee } \\
\text { Company }\end{array}$} & Travelers, Baggage, Travel Insurance & $\begin{array}{l}\text { Cover medical bills in case of accidents } \\
\text { and related loss }\end{array}$ \\
\hline & Excess Protector & Personal and domestic asset coverage \\
\hline & $\begin{array}{l}\text { Index Insurance: Sorghum; Sugarcane; } \\
\text { Hail Storm; Drought Insurance }\end{array}$ & $\begin{array}{l}\text { Crop insurance against adverse weather } \\
\text { vagaries }\end{array}$ \\
\hline & Livestock Insurance & Covers against livestock losses \\
\hline & Office Combined & Cover against business losses \\
\hline & Baada ya Campo Life Product & Covers graduates against medical bills \\
\hline \multirow{3}{*}{$\begin{array}{l}\text { Monarch } \\
\text { Company }\end{array}$} & Golfer's Policy & Policies for Golf amateurs \\
\hline & Office Combined & Cover against business losses \\
\hline & Travellers Package & $\begin{array}{l}\text { Cover medical bills in case of accidents } \\
\text { and related loss }\end{array}$ \\
\hline \multirow[t]{4}{*}{$\begin{array}{l}\text { UAP } \\
\text { Company }\end{array}$} & Salamasure & $\begin{array}{l}\text { Cover medical bills in case of accidents } \\
\text { and related loss }\end{array}$ \\
\hline & Biasharasure & Cover against business losses \\
\hline & Trucksure & Covers goods on transit \\
\hline & Life-Credit Life and Group Life & $\begin{array}{l}\text { Compensation for dependants in case of } \\
\text { policyholders death }\end{array}$ \\
\hline \multirow{2}{*}{$\begin{array}{l}\text { Pioneer } \\
\text { Company }\end{array}$} & Heshima Mpango Poa & Covers informal traders against loss \\
\hline & Medlife Afya & $\begin{array}{l}\text { Medical bill coverage for policyholders } \\
\text { and family }\end{array}$ \\
\hline
\end{tabular}

Table 1 shows the micro-insurance products offered by the responding companies. The most popular micro-insurance policy covers medical bills. 
Table 2. Characteristics of the respondents

\begin{tabular}{|c|c|c|c|}
\hline & & $\mathrm{N}$ & $\%$ \\
\hline \multirow[t]{5}{*}{ Job experience } & Less than 2 years & 29 & 59.2 \\
\hline & $3-4$ years & 1 & 2.0 \\
\hline & $5-6$ years & 9 & 18.4 \\
\hline & More than 6 years & 10 & 20.4 \\
\hline & & 49 & 100 \\
\hline \multirow{5}{*}{ Management Level } & Operations & 22 & 45.0 \\
\hline & Top & 2 & 4 \\
\hline & Middle & 17 & 35 \\
\hline & Lower & 8 & 16 \\
\hline & & 49 & 100 \\
\hline \multirow[t]{5}{*}{ Departments } & Underwriting & 31 & 63.3 \\
\hline & Risk management & 4 & 8.2 \\
\hline & Claims & 1 & 2.0 \\
\hline & $\begin{array}{l}\text { Marketing, product design, } \\
\text { strategy }\end{array}$ & 13 & 26.5 \\
\hline & & 49 & 100 \\
\hline \multirow{4}{*}{$\begin{array}{l}\text { Duration that the companies } \\
\text { had offered micro-insurance }\end{array}$} & Less than 3 years & 1 & 12.5 \\
\hline & $4-5$ years & 3 & 37.5 \\
\hline & 6 years or more & 4 & 50.0 \\
\hline & & 8 & 100 \\
\hline \multirow[t]{6}{*}{$\begin{array}{l}\text { Chances of renewal of } \\
\text { policies }\end{array}$} & Less than $20 \%$ & 6 & 12.2 \\
\hline & $21-40 \%$ & 13 & 26.5 \\
\hline & $41-60 \%$ & 14 & 28.6 \\
\hline & $61-80 \%$ & 15 & 30.6 \\
\hline & $81-100 \%$ & 1 & 2.0 \\
\hline & & 49 & 100 \\
\hline
\end{tabular}

Table 2 details the profile of the respondents and their companies. Majority of them have worked for less than 2 years in micro-insurance, are in mainstream management, work in the underwriting department. Half of the companies have offered micro-insurance services for more than six years.

Table 3. Micro-insurance risks faced by insurance companies

\begin{tabular}{|c|c|c|c|c|c|c|c|}
\hline Micro-insurance Risks & $\begin{array}{l}\bar{Z} \\
\sum \\
z \\
z \\
z \\
z\end{array}$ & 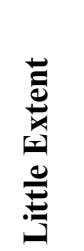 & 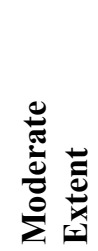 & 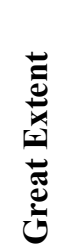 & 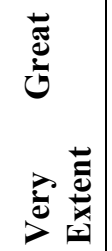 & $\sum_{\bar{\Xi}}^{\tilde{\Xi}}$ & 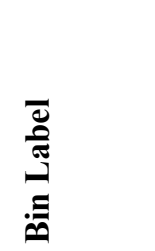 \\
\hline $\begin{array}{l}\text { Product design challenges (products not meeting clients } \\
\text { needs) }\end{array}$ & 8.2 & 34.7 & 46.9 & 10.2 & .0 & 2.59 & Not a risk \\
\hline $\begin{array}{l}\text { Adverse selection risks (underwriting risky clientele due } \\
\text { to incomplete/false information about them) }\end{array}$ & 4.1 & 40.8 & 14.3 & 34.7 & 6.1 & 2.98 & Not a risk \\
\hline $\begin{array}{l}\text { Moral hazard risks (low end consumers risk-taking } \\
\text { behavior increases their likelihood) }\end{array}$ & 0 & 30.6 & 26.5 & 34.7 & 6.1 & 3.12 & Severe \\
\hline
\end{tabular}




\begin{tabular}{|l|l|l|l|l|l|l|l|}
\hline $\begin{array}{l}\text { Pricing vs. cost risks (Micro-Insurance policy price is } \\
\text { lower than the administrative cost incurred, thus } \\
\text { unprofitable) }\end{array}$ & 0 & 26.5 & 42.9 & 20.4 & 10.2 & 3.14 & Severe \\
\hline $\begin{array}{l}\text { Correlations of risks (in Micro-insurance, an event } \\
\text { occurrence hurts a large percentage of the insured } \\
\text { clients) }\end{array}$ & 2.0 & 18.4 & 44.9 & 26.5 & 8.2 & 3.20 & Very severe \\
\hline $\begin{array}{l}\text { Rigid regulation framework in Kenya is a limitation to } \\
\text { Micro-Insurance provision }\end{array}$ & 6.1 & 14.3 & 30.6 & 30.6 & 18.4 & 3.41 & Very severe \\
\hline Micro-Insurance is more prone to fraudulent claims & 0 & 22.4 & 44.9 & 32.7 & 0.0 & 3.10 & Severe \\
\hline $\begin{array}{l}\text { Micro-Insurance has a high prevalence of premium } \\
\text { defaults (policy lapse) }\end{array}$ & 0 & 42.9 & 30.6 & 20.4 & 6.1 & 2.90 & Not a risk \\
\hline $\begin{array}{l}\text { Limited distribution channel constrains micro-insurance } \\
\text { sector }\end{array}$ & 2.0 & 8.2 & 20.4 & 57.1 & 12.2 & 3.69 & Very severe \\
\hline $\begin{array}{l}\text { Micro-Insurance experiences low penetration hence } \\
\text { diseconomies of scale }\end{array}$ & 0 & 4.1 & 24.5 & 32.7 & 38.8 & 4.06 & Very severe \\
\hline
\end{tabular}

Table 3 shows the risks faced by micro-insurance service providers on a 5-point scale. The factors are categorized by use of visual binning at \pm 1 standard deviation.

Table 4. Correlation analysis on risks faced by micro-insurance service providers

\begin{tabular}{|c|c|c|c|c|c|c|c|}
\hline & & 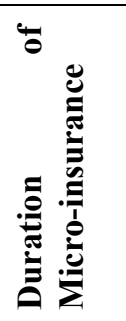 & 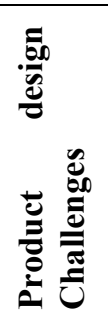 & 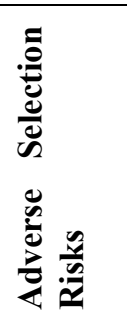 & 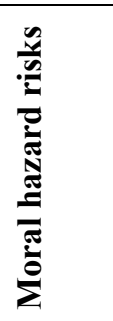 & 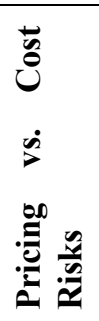 & 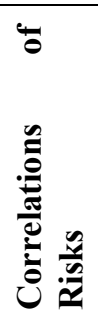 \\
\hline \multirow{2}{*}{$\begin{array}{l}\text { Product design } \\
\text { challenges }\end{array}$} & Pearson Correlation & .022 & 1 & .039 & .092 & .278 & $.350^{*}$ \\
\hline & Sig. (2-tailed) & .880 & & .792 & .530 & .053 & .014 \\
\hline \multirow{2}{*}{$\begin{array}{l}\text { Adverse selection } \\
\text { risks }\end{array}$} & Pearson Correlation & $.450^{* *}$ & .039 & 1 & $.503 * *$ & .126 & -.038 \\
\hline & Sig. (2-tailed) & .001 & .792 & & .000 & .390 & .797 \\
\hline \multirow[t]{2}{*}{ Moral hazard risks } & Pearson Correlation & .124 & .092 & $.503^{* *}$ & 1 & -.019 & .179 \\
\hline & Sig. (2-tailed) & .398 & .530 & .000 & & .896 & .219 \\
\hline \multirow{2}{*}{$\begin{array}{l}\text { Pricing vs. cost } \\
\text { risks }\end{array}$} & Pearson Correlation & -.075 & .278 & .126 & -.019 & 1 & .063 \\
\hline & Sig. (2-tailed) & .609 & .053 & .390 & .896 & & .668 \\
\hline \multirow{2}{*}{$\begin{array}{l}\text { Correlations of } \\
\text { risks }\end{array}$} & Pearson Correlation & $-.313^{*}$ & $.350^{*}$ & -.038 & .179 & .063 & 1 \\
\hline & Sig. (2-tailed) & .029 & .014 & .797 & .219 & .668 & \\
\hline \multirow{3}{*}{$\begin{array}{l}\text { Microinsurance } \\
\text { experiences low } \\
\text { penetration }\end{array}$} & Pearson Correlation & $-.500 * *$ & .036 & $-.466^{* *}$ & -.172 & .212 & .137 \\
\hline & Sig. (2-tailed) & .000 & .806 & .001 & .237 & .143 & .349 \\
\hline & $\mathrm{N}$ & 49 & 49 & 49 & 49 & 49 & 49 \\
\hline
\end{tabular}

**. Correlation is significant at the 0.01 level (2-tailed). *. Correlation is significant at the 0.05 level (2-tailed).

Table 4 shows a correlation matrix of the risks faced by micro-insurance service providers. 
Table 5. Risk management practices of insurance firms

\begin{tabular}{|c|c|c|c|c|c|c|c|}
\hline Risk Management Practices & \begin{tabular}{l}
$\sum_{2}$ \\
\multirow{2}{*}{} \\
$\stackrel{0}{Z}$ \\
2
\end{tabular} & 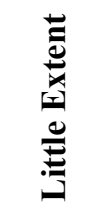 & 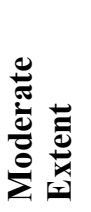 & 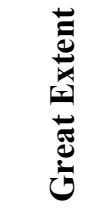 & 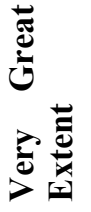 & $\sum_{\Sigma}^{\mathbb{E}}$ & 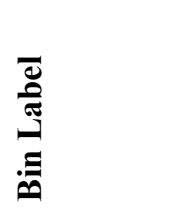 \\
\hline Constant monitoring of clients risk profile & 0 & 14.3 & 46.9 & 34.7 & 4.1 & 3.29 & $\begin{array}{l}\text { Rarely } \\
\text { used }\end{array}$ \\
\hline $\begin{array}{l}\text { Control of moral hazards by denying claims to self-inflicted or } \\
\text { aggravated losses }\end{array}$ & 0 & 12.2 & 20.4 & 46.9 & 20.4 & 3.76 & $\begin{array}{l}\text { Frequently } \\
\text { used }\end{array}$ \\
\hline Conducting constant Micro-Insurance price reviews/revision & 0 & 22.4 & 28.6 & 36.7 & 12.2 & 3.39 & $\begin{array}{l}\text { Frequently } \\
\text { used }\end{array}$ \\
\hline $\begin{array}{l}\text { Using technology to minimize Micro-Insurance administration } \\
\text { costs }\end{array}$ & 2.0 & 4.1 & 30.6 & 26.5 & 36.7 & 3.92 & $\begin{array}{l}\text { Frequently } \\
\text { used }\end{array}$ \\
\hline $\begin{array}{l}\text { Mitigating against adverse selection by excluding areas/clients } \\
\text { of high risks probability }\end{array}$ & 2.0 & 18.4 & 18.4 & 42.9 & 18.4 & 3.57 & $\begin{array}{l}\text { Frequently } \\
\text { used }\end{array}$ \\
\hline Thorough scrutiny of Micro-Insurance claims & 0 & 8.2 & 46.9 & 34.7 & 10.2 & 3.47 & $\begin{array}{l}\text { Frequently } \\
\text { used }\end{array}$ \\
\hline Development of risk measurement models & 2.0 & 16.3 & 32.7 & 42.9 & 6.1 & 3.35 & $\begin{array}{l}\text { Frequently } \\
\text { used }\end{array}$ \\
\hline $\begin{array}{l}\text { Using actuarial services to perform risk analysis of new } \\
\text { products before releasing it to the market }\end{array}$ & 2.0 & 26.5 & 24.5 & 36.7 & 10.2 & 3.27 & $\begin{array}{l}\text { Rarely } \\
\text { used }\end{array}$ \\
\hline $\begin{array}{l}\text { Giving clients a flexible premium payment terms to avoid } \\
\text { non-payment }\end{array}$ & 4.1 & 10.2 & 55.1 & 18.4 & 12.2 & 3.24 & $\begin{array}{l}\text { Rarely } \\
\text { used }\end{array}$ \\
\hline $\begin{array}{l}\text { Partnering with other companies to risks, hence, } \\
\text { micro-insurance cost }\end{array}$ & 2.0 & 28.6 & 24.5 & 26.5 & 18.4 & 3.31 & $\begin{array}{l}\text { Rarely } \\
\text { used }\end{array}$ \\
\hline $\begin{array}{l}\text { Conducting campaigns on insurance to boost public } \\
\text { awareness/confidence, thus, raise penetration }\end{array}$ & 6.1 & 24.5 & 24.5 & 20.4 & 24.5 & 3.33 & $\begin{array}{l}\text { Rarely } \\
\text { used }\end{array}$ \\
\hline Reinsuring Micro-Insurance products & 12.2 & 26.5 & 20.4 & 26.5 & 14.3 & 3.04 & $\begin{array}{l}\text { Rarely } \\
\text { used }\end{array}$ \\
\hline
\end{tabular}

Table 5 discusses the risk management practices that micro-insurance service providers in Kenya are currently using. The factors are categorized by use of visual binning at \pm 1 standard deviation.

Table 6. Line of business and monitoring of clients risk profile

\begin{tabular}{|l|l|l|l|}
\hline & Value & df & Asymp. Sig. (2-sided) \\
\hline Pearson Chi-Square & $14.883^{\mathrm{a}}$ & 6 & .021 \\
\hline Likelihood Ratio & 14.607 & 6 & .024 \\
\hline Linear-by-Linear Association & 2.432 & 1 & .119 \\
\hline N of Valid Cases & 49 & & \\
\hline
\end{tabular}

Table 6 shows the results of Pearson Chi-square. It discloses strong association between the insurance company's line of business and monitoring of the client's risk profile.

Table 7. Line of business and mitigating against adverse selection risks

\begin{tabular}{|l|l|l|l|}
\hline & Value & df & Asymp. Sig. (2-sided) \\
\hline Pearson Chi-Square & $22.965^{\mathrm{a}}$ & 8 & .003 \\
\hline Likelihood Ratio & 27.566 & 8 & .001 \\
\hline Linear-by-Linear Association & 1.132 & 1 & .287 \\
\hline N of Valid Cases & 49 & & \\
\hline
\end{tabular}

Table 7 shows the results of Pearson Chi-square. It discloses strong association between the insurance company's line of business and mitigation of adverse risks. 
Table 8. Line of business and monitoring of micro-insurance claims

\begin{tabular}{|l|l|l|l|}
\hline & Value & df & Asymp. Sig. (2-sided) \\
\hline Pearson Chi-Square & $13.161^{\mathrm{a}}$ & 6 & .041 \\
\hline Likelihood Ratio & 14.182 & 6 & .028 \\
\hline Linear-by-Linear Association & 3.222 & 1 & .073 \\
\hline N of Valid Cases & 49 & & \\
\hline
\end{tabular}

Table 8 shows the results of Pearson Chi-square. It discloses strong association between the insurance company's line of business and monitoring of micro-insurance claims.

Table 9. Market served and use of mobile money transfer

\begin{tabular}{|l|l|l|l|}
\hline & Value & df & Asymp. Sig. (2-sided) \\
\hline Pearson Chi-Square & $16.516^{\mathrm{a}}$ & 8 & .036 \\
\hline Likelihood Ratio & 16.228 & 8 & .039 \\
\hline Linear-by-Linear Association & .008 & 1 & .928 \\
\hline N of Valid Cases & 49 & & \\
\hline
\end{tabular}

Table 9 shows the results of Pearson Chi-square. It discloses strong association between market served by the insurance company and the use of mobile money transfer in the collection of premiums.

Table 10. Market served and development of risk measurement models

\begin{tabular}{|l|l|l|l|}
\hline & Value & Df & Asymp. Sig. (2-sided) \\
\hline Pearson Chi-Square & $17.951^{\mathrm{a}}$ & 8 & .022 \\
\hline Likelihood Ratio & 17.954 & 8 & .022 \\
\hline Linear-by-Linear Association & .114 & 1 & .736 \\
\hline N of Valid Cases & 49 & & \\
\hline
\end{tabular}

Table 10 shows the results of Pearson Chi-square. It discloses strong association between market served by the insurance company and the development of risk measurement models

Table 11. Market served and reinsurance of micro-insurance products

\begin{tabular}{|l|l|l|l|}
\hline & Value & df & Asymp. Sig. (2-sided) \\
\hline Pearson Chi-Square & $31.200^{\mathrm{a}}$ & 8 & .000 \\
\hline Likelihood Ratio & 34.535 & 8 & .000 \\
\hline Linear-by-Linear Association & 1.106 & 1 & .293 \\
\hline N of Valid Cases & 49 & & \\
\hline
\end{tabular}

Table 11 shows the results of Pearson Chi-square. It discloses strong association between market served by the insurance company and the use of re-insurance as a risk mitigation strategy. 
Table 12. Risk mitigation strategies in the micro-insurance provision

\begin{tabular}{|l|l|l|l|l|l|l|l|}
\hline Recommendations & & & & & & & \\
\hline $\begin{array}{l}\text { Insurance firms need to reduce administration cost through } \\
\text { technology and partnerships }\end{array}$ & 0.0 & 0.0 & 20.4 & 28.6 & 51.0 & 4.31 & Very effective \\
\hline $\begin{array}{l}\text { Insurance firms need to formulate innovative distribution } \\
\text { channel (like use of agents) }\end{array}$ & 0.0 & 0.0 & 16.3 & 42.9 & 40.8 & 4.24 & Very effective \\
\hline $\begin{array}{l}\text { Insurance firms need to conduct public awareness } \\
\text { campaigns and education on Micro-Insurance benefits }\end{array}$ & 0.0 & 0.0 & 16.3 & 22.4 & 61.2 & 4.45 & Very effective \\
\hline $\begin{array}{l}\text { Develop selective targeting of geographical areas and } \\
\text { clientele demographic to reduce adverse selection }\end{array}$ & 2.0 & 14.3 & 4.1 & 46.9 & 32.7 & 3.94 & Effective \\
\hline $\begin{array}{l}\text { Should enlist the use of sponsors/partners so as to offer } \\
\text { Micro-Insurance at subsidized rate }\end{array}$ & 0.0 & 12.2 & 10.2 & 53.1 & 24.5 & 3.90 & Effective \\
\hline $\begin{array}{l}\text { Insurance companies should make use of flexible premium } \\
\text { payment terms/mode }\end{array}$ & 0.0 & 4.1 & 12.2 & 26.5 & 57.1 & 4.37 & Very effective \\
\hline $\begin{array}{l}\text { Prices adjustment to reflect loss or discount offered where } \\
\text { perceived high risk areas turn-out not to be }\end{array}$ & 0.0 & 2.0 & 34.7 & 28.6 & 34.7 & 3.96 & Effective \\
\hline $\begin{array}{l}\text { Should invest in research and development or actuarial } \\
\text { services to help in pricing of products }\end{array}$ & 0.0 & 2.0 & 2.0 & 36.7 & 59.2 & 4.53 & Very effective \\
\hline $\begin{array}{l}\text { Insurance companies should come up risk reference } \\
\text { bureaus' where clients' risk profile can be shared }\end{array}$ & 0.0 & 8.2 & 18.4 & 40.8 & 32.7 & 3.98 & Effective \\
\hline $\begin{array}{l}\text { Legislation should allow micro-insurance policies be } \\
\text { written in languages comprehensible to the locals }\end{array}$ & 2.0 & 0.0 & 12.2 & 34.7 & 51.0 & 4.33 & Very effective \\
\hline
\end{tabular}

Table 12 discusses the risk management practices that micro-insurance service providers in Kenya are currently using. The factors are categorized by use of visual binning at \pm 1 standard deviation.

Table 13. Line of business and administration cost reduction through technology

\begin{tabular}{|l|l|l|l|}
\hline & Value & df & Asymp. Sig. (2-sided) \\
\hline Pearson Chi-Square & $15.328^{\mathrm{a}}$ & 4 & .004 \\
\hline Likelihood Ratio & 15.510 & 4 & .004 \\
\hline Linear-by-Linear Association & 1.978 & 1 & .160 \\
\hline N of Valid Cases & 49 & & \\
\hline
\end{tabular}

Table 13 shows the results of Pearson Chi-square. It discloses strong association between line of business that the insurance company serves and the use of technology to lower administration costs.

Table 14. Line of business and need for flexibility in premium payment

\begin{tabular}{|l|l|l|l|}
\hline & Value & df & Asymp. Sig. (2-sided) \\
\hline Pearson Chi-Square & $27.870^{\mathrm{a}}$ & 6 & .000 \\
\hline Likelihood Ratio & 34.242 & 6 & .000 \\
\hline Linear-by-Linear Association & 5.145 & 1 & .023 \\
\hline N of Valid Cases & 49 & & \\
\hline
\end{tabular}

Table 14 shows the results of Pearson Chi-square. It discloses strong association between line of business that the insurance company serves and the need for flexibility in premium payment. 
Table 15. Market served and need for public awareness campaigns

\begin{tabular}{|l|l|l|l|}
\hline & Value & df & Asymp. Sig. (2-sided) \\
\hline Pearson Chi-Square & $13.409^{\mathrm{a}}$ & 4 & .009 \\
\hline Likelihood Ratio & 12.893 & 4 & .012 \\
\hline Linear-by-Linear Association & .633 & 1 & .426 \\
\hline N of Valid Cases & 49 & & \\
\hline
\end{tabular}

Table 15 shows the results of Pearson Chi-square. It discloses strong association between the market served by the insurance company and the need for public awareness to manage risks for micro-insurance providers.

Table 16. Market served and need for selective targeting of geographical areas

\begin{tabular}{|l|l|l|l|}
\hline & Value & df & Asymp. Sig. (2-sided) \\
\hline Pearson Chi-Square & $16.837^{\mathrm{a}}$ & 8 & .032 \\
\hline Likelihood Ratio & 18.732 & 8 & .016 \\
\hline Linear-by-Linear Association & 8.451 & 1 & .004 \\
\hline N of Valid Cases & 49 & & \\
\hline
\end{tabular}

Table 16 shows the results of Pearson Chi-square. It discloses strong association between line of business that the insurance company serves and the selective targeting of geographical areas as a risk management strategy for the micro-insurance services providers. 